\title{
Soft tissue chondroma of the hard palate: A case report
}

Toshihiro Kawano $^{\mathrm{a}}$, Souichi Yanamoto ${ }^{\mathrm{a}, *}$, Goro Kawasaki ${ }^{\mathrm{a}}$, Akio Mizuno ${ }^{\mathrm{a}}$, Shuichi Fujita ${ }^{b}$, Tohru Ikeda ${ }^{b}$

${ }^{a}$ Department of Oral and Maxillofacial Surgery, Unit of Translational Medicine, Course of Medical and Dental Sciences, Graduate School of Biomedical Sciences, Nagasaki University, 1-7-1 Sakamoto, Nagasaki 852-8588, Japan

${ }^{\mathrm{b}}$ Department of Oral Pathology and Bone Metabolism, Unit of Basic Medical Sciences, Course of Medical and Dental Sciences, Graduate School of Biomedical Sciences, Nagasaki University, 1-7-1 Sakamoto, Nagasaki 852-8588, Japan

Corresponding author. Tel.: +8195819 7698; fax: +81958197700 E-mail address: syana@nagasaki-u.ac.jp (S. Yanamoto).

Keywords: soft tissue chondroma; hard palate 


\section{ABSTRACT}

Soft tissue chondroma of the palate is a rare lesion. We report a rare case of soft tissue chondroma of the hard palate with a review of the literature. A 59-year-old man was referred to our department because of a symptomatic mass on the median anterior margin of the hard palate of 4 year's duration. The lesion was approximately $15 \times 10 \times 8 \mathrm{~mm}$ in size and pedunculated. The lesion was excised under local anesthesia, and the pathological diagnosis was soft tissue chondroma. The histopathological findings suggested that the heterotopic formation of cartilage was caused by the metaplastic change of mesenchymal cells into chondrocytes. Postoperative wound healing has been uneventful, with no sign of recurrence during 2 years after surgery.

Keywords: soft tissue chondroma, hard palate 


\section{Introduction}

A chondroma usually arises in the tubular bones of the four extremities, but it is extremely rare for this tumor to occur in soft tissue [1-4]. Soft tissue chondroma is a soft tissue mass containing histologically normal cartilage, usually found on the hands and feet $[3,4]$. Soft tissue chondroma of the oral tissue is a rare lesion, occurring most frequently on the tongue [5-33] but also found on the buccal mucosa [34-37], hard palate [38-40], gingiva [41, 42], soft palate [43], and lower lip [45].

In this paper, we report a rare case of soft tissue chondroma arising in the hard palate, present a review of the literature, and discuss the lesion's histogenesis.

\section{Case report}

A 59-year-old man was referred to our department for evaluation of a mass on the hard palate. Intra-oral examination revealed a pedunculated, non-tender, multilobulated mass covered with normal mucosa, approximately $15 \times 10 \times 8 \mathrm{~mm}$ in size, on the midline of hard palate, which had developed over a period of 4 years (Fig. 1). The clinical differential diagnosis included a fibroma or pleomorphic adenoma. The lesion was excised totally, with surrounding normal tissue, under local anesthesia.

Histologically, the pedunculated mucosa was covered with thick 
squamous epithelium. Several spherical nodules composed of spindle mesenchymal cells were found. Round inflammatory cell infiltration and fibrosis could be seen around the nodules (Fig. 2a), with some including myxoid change (Fig. 2b) and/or cartilaginous formation by chondrocytes (Fig. 2c). The mesenchymal cells and chondrocytes showed no atypia, and mitotic figures were seldom noticed. Immunohistochemical examination revealed that the mesenchymal cells and chondrocytes were positive for S-100 (Fig. 3a and b) and vimentin and negative for cytokeratin AE1/AE3 (Fig. 3c) and $\alpha$-SMA.

The histological diagnosis of soft tissue chondroma was made in consideration of ectopic cartilaginous tissues that localized within the pedunculated lesion apart from the maxillary bone.

The postoperative course was uneventful. No sign of recurrence was found at a follow-up examination 2 years after surgery.

\section{Discussion}

Soft tissue chondromas are ectopic tumor-like masses formed by the proliferation of chondrocytes in a mature hyaline matrix [29, 32]. Soft tissue chondroma of the oral cavity is rare; only 46 cases have been reported in the English literature (Table 1) [5-45]. The tongue was the most common site for soft tissue chondroma (33 of 46; 71.7\%), followed by 
buccal mucosa ( 4 of $46 ; 8.7 \%$ ), hard palate ( 4 of $46 ; 8.7 \%$ ), gingiva ( 3 of $46 ; 6.5 \%)$, soft palate ( 1 of $46 ; 2.2 \%)$, and lip ( 1 of $46 ; 2.2 \%)$. Patient age ranged from 3 to 79 years old (average 36.4 years old). Patients were 22 males and 24 females. Lesions ranged from $1.5 \mathrm{~mm}$ to $45 \mathrm{~mm}$ (average $14.7 \mathrm{~mm}$ in size). The mean disease duration was 6.86 years. In all reported cases, resection was performed and no sign of recurrence was observed. Soft tissue chondroma arising in the hard palate is extremely rare, and to our knowledge, only four previous accounts of a chondroma in the hard palate have been reported.

Although the origin of soft tissue chondroma is uncertain and controversial $[4,29,32]$, two theories are most widely accepted [28]. The "embryonic remnants theory" postulates that the lesion originates from heterotopic cartilage remnants from any of the first 4 branchial arches. It is suggested that chondroblastic cells could have been misplaced during development and sequestered in the tongue $[18,26]$. This theory could explain why soft tissue chondromas are so widely distributed in the tongue.

The "metaplastic theory" is supported by the fact that many patients have a history of trauma, chronic inflammation and X-ray irradiation, which could stimulate metaplasia [29, 46-49]. This theory is particularly attractive for explaining lesions located on the lateral border, ventral surface or tip of the tongue, especially in an older age group [17, 18, 21, 22, 
28, 32, 33]. Some papers have reported that traumatic cartilaginous metaplasia is also seen within flabby edentulous alveolar ridges in response to mechanical irritation caused by ill-fitting dentures [46, 47].

In our present case, it was evident that traumatic stimulation could have been caused by contact with the lower incisors. Moreover, microscopically, the mesenchymal cell nodules were surrounded by fibrous connective tissue infiltrated by lymphocytes and plasma cells. These mesenchymal cells were positive for S-100, even though cartilaginous formation was not detected. We suppose that S-100-positive cells were under metaplastic change toward chondrocytes, which was possibly induced by chronic inflammation; therefore, the origin of cartilage in our present case supports the "metaplastic theory".

The differential diagnosis includes pleomorphic adenoma predominantly composed of chondroid extracellular matrix [29]. In our case, however, the mesenchymal nodules were multiple and salivary glands were not included in the pedunculated mass. In addition, immunohistochemistry revealed negative reactions for both cytokeratin AE1/AE3 and $\alpha$-SMA in the nodules with or without cartilaginous tissue. These findings support the diagnosis of soft tissue chondroma.

Soft tissue chondromas are characterized by benign clinical behavior. Surgical excision is the treatment of choice. No recurrent cases have been 
reported in the literature. 


\section{References}

[1] Krolls SO, Jacoway JR, Alexander WN. Osseous choristomas (Osteomas) of intraoral soft tissues. Oral Surg Oral Med Oral Pathol 1971; 32: $588-95$.

[2] Chou L, Hansen LS, Daniels TE. Choristomas of the oral cavity: a review. Oral Surg Oral Med Oral Pathol 1991; 72: 584-93.

[3] Dahlin DC, Salvador AH. Cartilaginous tumors of the soft tissues of the hands and feet. Mayo Clin Proc 1974; 49: 721-6

[4] Han JY, Han HS, Kim YB, Kim JM, Chu YC. Extraskeltal chondroma of the fallopian tube. J Korean Med Sci 2002; 17: 276-8

[5] Johns J. Chondroma of the tongue. J Michigan State Med Soc 1942; 41: $471-2$

[6] Bruce KW, McDonald JR. Chondroma of the tongue. Oral Surg Med Oral Pathol 1953; 6: 1281-3.

[7] Rosen MD. Chondroma of the tongue: report of case. J Oral Surg Anesth Hosp Dent Serv 1961; 19: 157-9.

[8] Yoel J, Pundyk C. Chondroma of the tongue. Oral Surg Oral Med Oral Pathol 1965; 20: 578-82.

[9] Ramachandran K, Viswanathan R. Chondroma of the tongue. Report of a case. Oral Surg Oral Med Oral Pathol 1968; 25: 487-90.

[10] Samant HC, Gupta OP. Chondroma of the tongue. Oral Surg Oral Med 
Oral Pathol 1971; 32: 450-2.

[11] Zagarelli DJ. Chondroma of the tongue. Oral Surg Oral Med Oral Pathol 1977; 43: 736-45.

[12] del Rio CE. Chondroma of the tongue: review of the literature and a case report. J Oral Med 1978; 33:54-6.

[13] Segal K, Sidi J, Katzav Y, Rotem A. Chondroma of the tongue: Report of two cases. Ann Otol Rhinol Laryngol 1984; 93: 271-2.

[14] Yasuoka T, Hanada Y, Watanabe F, Oka N. Chondoroma of the tongue; Report of a case. J Maxillofac Surg 1984; 12: 188-91.

[15] Ling KC. Chondroma of the tongue. J Oral Maxillofac Surg 1986; 44: $159-8$.

[16] Tohill MJ, Green JG, Cohen DM. Intraoral osseous and cartilaginous choristomas: report of three cases and review of the literature. Oral Surg Oral Med Oral Pathol 1987; 63: 506-10.

[17] van del Wal N, van del Waal I. Osteoma or chondroma of the tongue; a clinical and postmortem study. Int J Oral Maxillofac Surg 1987; 16: 713-7. [18] Weitzner S, Stimson PG, McClendon JL. Cartilaginous choristoma of the tongue. J Oral Maxillofac Surg 1987; 45: 185-7.

[19] West CB Jr, Atkins JS Jr. Choristomas of the intraoral soft tissues. Otolaryngol Head Neck Surg 1988; 99: 528-30.

[20] Aguirre JM, Martinez-Conde R, Tanago JG, Rivera Pomar JM. 
Chondroma of the tongue. Int J Oral Maxillofac Surg 1988; 17: 285-7.

[21] Ishibashi T, Nomura Y, Kojimabara M. Chondroma of the tongue. ORL J Otorhinolaryngol Relat Spec 1989; 51: 182-6.

[22] Tani Y, Azuma T, Nagayama M. Chondroma of the tongue. J Oral Maxillofac Surg 1989; 47: 91-2.

[23] Landini G, Kitano M, Urago A, Sugihara K, Yamashita S. Chondroma and osteochondroma of the tongue. Oral Surg Oral Med Oral Pathol 1989; 68: 206-9.

[24] Trowbridge M, McCabe B, Reznicek M. Cartilaginous choristoma of the tongue. A case report and literature review. Arch Otolaryngol Head Neck Surg 1989; 115: 627-9.

[25] Munro JM, Singh MP. Chondroma of the tongue. Arch otolaryngol Head Neck Surg 1989; 115: 627-9.

[26] Moore K, Worthington P, Campbell RL. Firm mass of the tongue. J Oral Maxillofac Surg 1990; 48: 1206-10.

[27] Sanchez-Aniceto G, Garcia-Penin A, Ballestin C. Chondrome lingual. Rev Stomatol Chir Maxillofac 1990; 91: 480-2.

[28] Mosqueda-Taylor A, Gonzalez-Guevara M, de la Piedra-Garza JM, Diaz-Franco MA, Toscano-Garcia 1, Cruz-Leon A. Cartilaginous choristoma of the tongue: Review of the literature and report of three cases. J Oral Pathol Med 1998; 27: 283-6. 
[29] Toida M, Sugiyama T, Kato Y. Cartilaginous choristoma of the tongue. J Oral Maxillofac Surg 2003; 61: 393-6.

[30] Sera H, Shimoda T, Ozeki S, Honda T. A case of chondroma of the tongue. Int J Oral Maxillofac Surg 2005; 34: 99-100.

[31] Mataix J, Botella R, Banus J, Gujiarro J, Pastor N, Betlloch I. Asymptomatic nodule of the tongue. Cartilaginous choristoma of the tongue. Arch Dermatol 2007; 143: 653-8.

[32] Desmedt M, Weynand B, Reychler H. Cartilaginous choristoma of the oral cavity: a report of two cases. B-ENT 2007; 3: 87-91.

[33] Rossi-Schneider TR, Salum FG, Cherubini K, Yurgel LS, Figuredo MA. Cartilaginous choristoma of the tongue. Gerodontology 2009; 26: $78-80$

[34] Hankey GT, Waterhouse JP. A calcifying chondroma in the cheek. Br J Oral Surg 1968; 5: 239-44.

[35] Sultani FA, Krolls SO, Heckler FR. Cartilaginous choritoma of buccal mucosa: a case report. Br J Plast Surg 1983; 36: 395-7.

[36] Blum MR, Danford M, Speight PM. Soft tissue chondroma of the cheek. J Oral Pathol Med 1993; 22: 334-6.

[37] Onodera K, Xu H, Kimizuka S, Echigo S, Ooya K. Chondroma of the cheek: A case report. Int J Oral Maxillofac Surg 2005; 34: 924-6.

[38] Ramanathan K, Keat TC, Singh H. Chondroma of the palate. Case 
report. Aust Dent J 1970; 15: 478-81.

[39] Snyder SR, Merkow LP. Benign chondroma of the palate: report of case. J Oral Surg 1973; 31: 873-5.

[40] Ide F. Chondromyxoid tumor of palate. J Oral Pathol Med 2006; 35: $523-4$.

[41] Unal T, Erturk S. Cartilaginous choristoma of the gingiva. Report of two cases; review of the literature of both gingival choristomas and intraoral chondromas. Ann Dent 1994; 53: 19-27.

[42] Matsushita K, Tahara M, Sato H, Nakamura E, Fujiwara T. Cartilaginous choristoma deep in the upper midline oral vestibule. $\mathrm{Br} \mathrm{J}$ Oral Maxillofac Surg 2004; 42: 436-8.

[43] Gardner DG, Paterson JC. Chondroma or metaplastic chondosis of soft palate. Oral Surg Oral Med Oral Pathol 1968; 26: 601-4.

[45] Kim Y, Moses M, Zegarelli DJ, Yoon AJ. Cartilaginous choristoma (soft tissue chondroma) : a rare presentation in the lower lip. J Clin Pediatr Dent 2009; 33: 253-4.

[46] Cutright DE. Osseous and chondromatous metaplasia caused by dentures. Oral Surg Oral Med Oral pathol 1972; 34: 625-33.

[47] Magnusson BC, Engstrom H, Kahnberg KE. Metaplastic formation of bone and chondroid in flabby ridges. Br J Oral Maxillofac Surg 1986; 24: $300-5$. 
[48] Takeda Y. Cartilaginous metapalasia of the human aponeurosis linguae: histologic and ultrasutructural study. J Oral Med 1987; 42: 35-7. [49] Lloyd S, Lloyd J, Dhillon R. Chondroid metaplasia in a fibroepithelial polyp of the tongue. J Laryngol Otol 2001; 115: 681-2. 


\section{Figure legends}

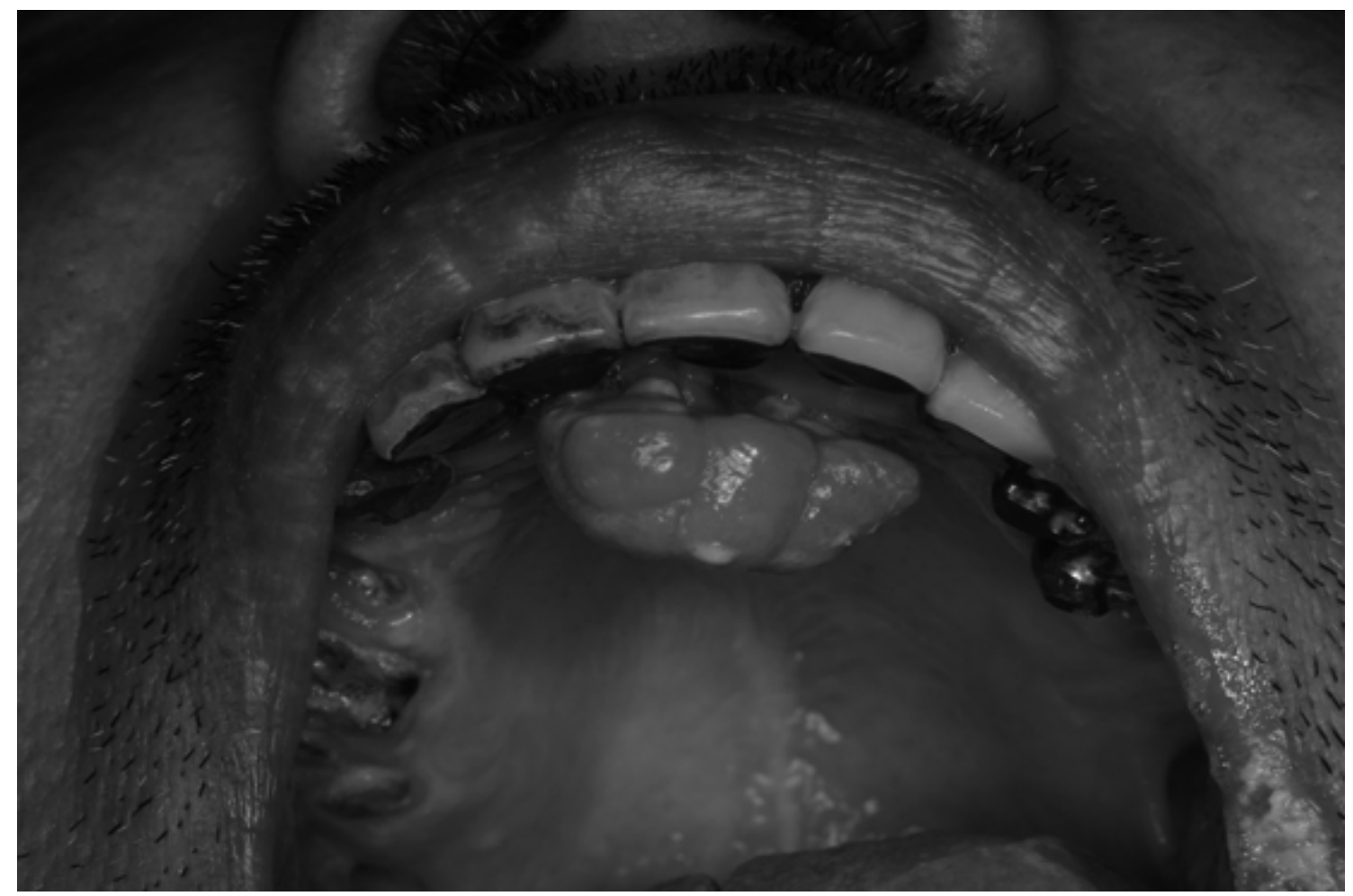

Fig. 1. Clinical appearance of a pedunculated mass covered with normal mucosa of the hard palate. 
(a)

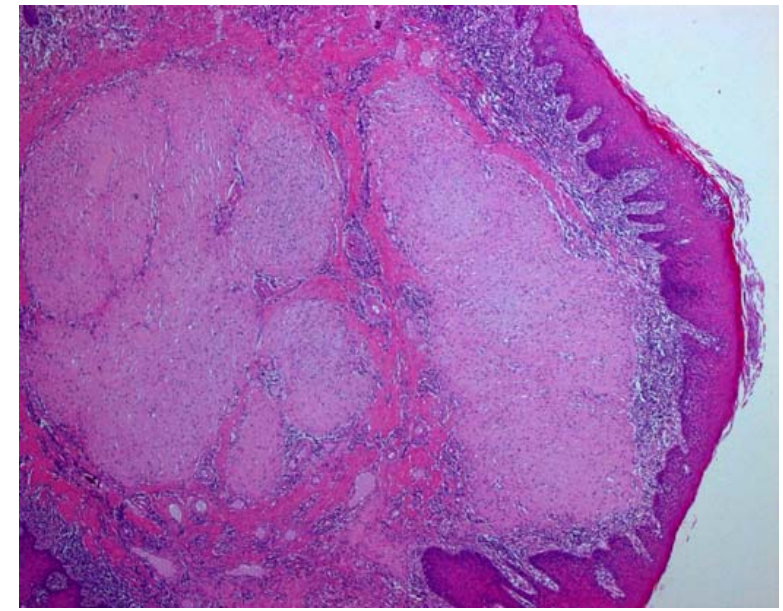

(b)

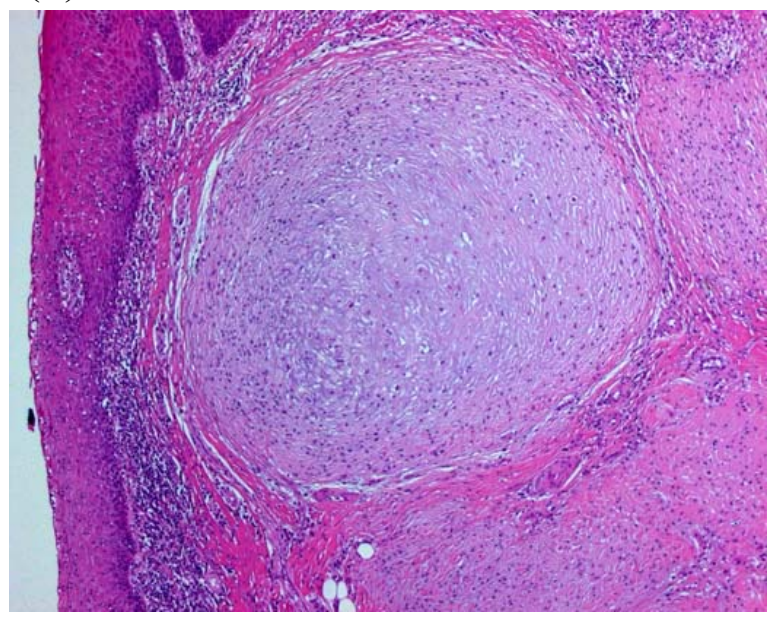

(c)

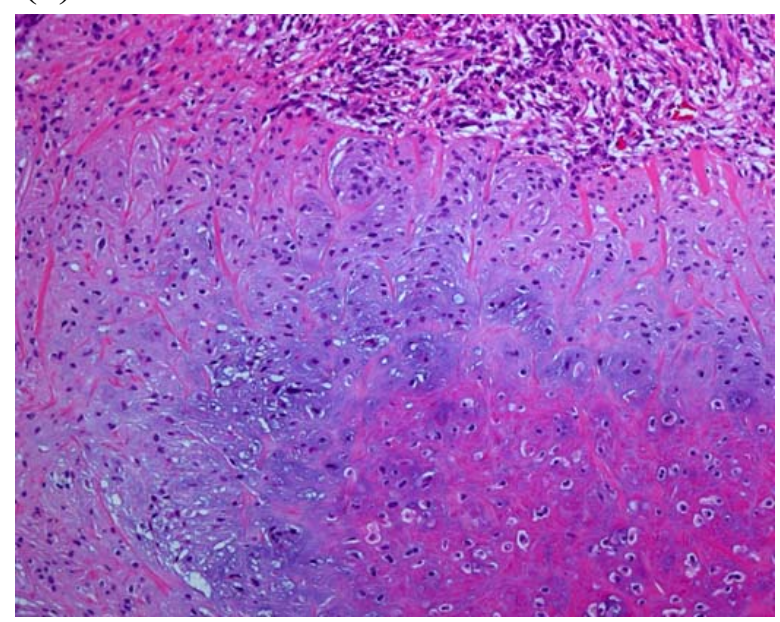

Fig. 2. Histopathological examination of the excised specimen. (a) Submucous spherical nodules composed of mesenchymal cells with fibrous tissue. Circumscribed by hyalinous connective tissue and round inflammatory cell infiltration (hematoxylin and eosin; original magnification, 50×). (b) Mesenchymal cell nodule showing myxoid change in the center (hematoxylin and eosin; original magnification, 50×). (c) Mesenchymal cell nodule containing cartilaginous formation (hematoxylin and eosin; original magnification, $100 \times$ ). 
(a)

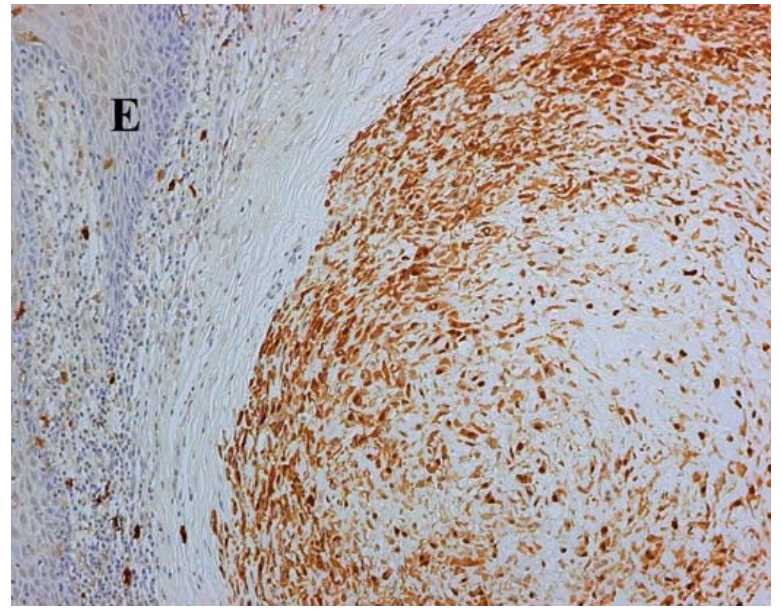

(b)

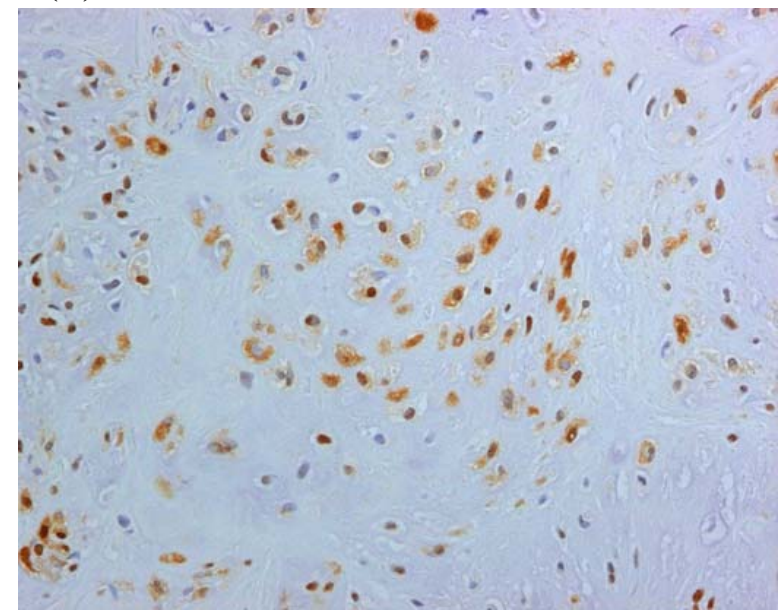

(c)

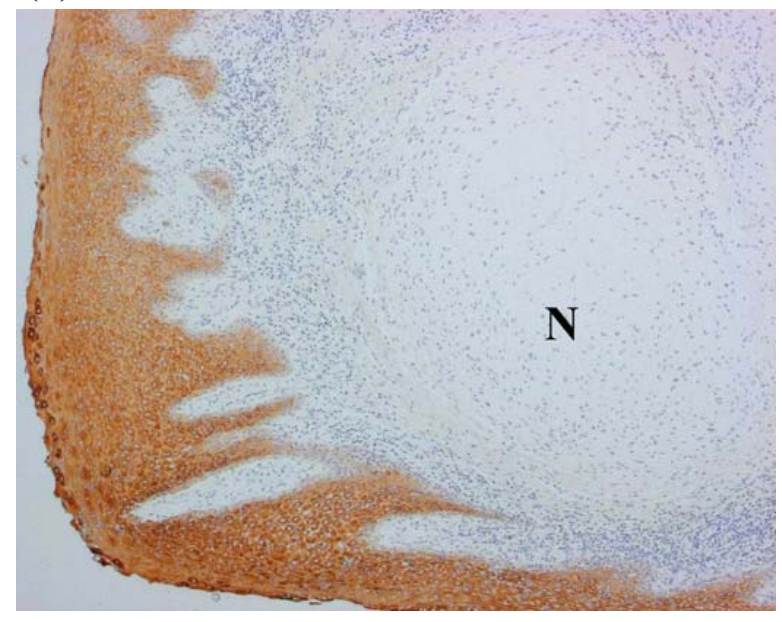

Fig. 3. Immunohistochemical examination. (a) Spindle mesenchymal cells demonstrating immunoreactivity with S-100. This nodule does not contain cartilaginous formation: E, Squamous epithelium (original magnification, $100 \times$ ). (b) Chondrocytes associating with cartilaginous formation are also positive for S-100 (original magnification, 200×). (c) Cytokeratin AE1/AE3 is expressed in mucosal epithelium but not in the mesenchymal cell nodule (N) (original magnification, $50 \times$ ). 
Table 1 Clinical features of cases of soft tissue chondroma of the oral cavity reported in the English literature since1942

\begin{tabular}{|c|c|c|c|c|c|c|c|c|}
\hline Case No. & $\begin{array}{c}\text { Reported } \\
\text { year }\end{array}$ & Author & Age (yr) & Gender & Location of lesion & $\begin{array}{c}\begin{array}{c}\text { Size of lesion } \\
(\mathrm{mm})\end{array} \\
\end{array}$ & Duration (yr) & $\begin{array}{c}\text { Reference } \\
\text { No. }\end{array}$ \\
\hline 1 & 1942 & Johns & Not described & M & Margin of tongue & Not described & 20 & 5 \\
\hline 2 & 1953 & Bruce et al. & 52 & M & Dorsum of tongue & 5 & 2 & 6 \\
\hline 3 & 1953 & Bruce et al. & 43 & $\mathrm{~F}$ & Dorsum of tongue & 3 & 1 & 6 \\
\hline 4 & 1961 & Rosen & 36 & M & Dorsum of tongue & 20 & 20 & 7 \\
\hline 5 & 1965 & Yoel et al. & 36 & M & Dorsum of tongue & 45 & 8 & 8 \\
\hline 6 & 1968 & Ramachandran et al. & 10 & $\mathrm{~F}$ & Dorsum of tongue & 10 & 2 & 9 \\
\hline 7 & 1968 & Gardner et al. & 20 & $\mathrm{~F}$ & Soft palate & 1.5 & Not described & 43 \\
\hline 8 & 1968 & Hankey et al. & Not described & $\mathrm{F}$ & Buccal mucosa & Not described & Not described & 34 \\
\hline 9 & 1970 & Ramanathan et al. & 53 & $\mathrm{~F}$ & Hard palate & 25 & 0.4 & 38 \\
\hline 10 & 1971 & Samant et al. & 16 & M & Dorsum of tongue & 25 & 6 & 10 \\
\hline 11 & 1973 & Snyder et al. & 24 & M & Hard palate & 20 & Not described & 39 \\
\hline 12 & 1977 & Zagarelli & 50 & $\mathrm{~F}$ & Facies Inferior of tongue & 5 & Not described & 11 \\
\hline 13 & 1978 & del Rio & 21 & M & Facies Inferior of tongue & 5 & Not described & 12 \\
\hline 14 & 1983 & Sultani et al. & 17 & M & Buccal mucosa & 25 & 0.17 & 35 \\
\hline 15 & 1984 & Segal et al. & 5 & M & Margin of tongue & 20 & 5 & 13 \\
\hline 16 & 1984 & Segal et al. & 30 & M & Margin of tongue & 15 & 30 & 13 \\
\hline 17 & 1984 & Yasuoka et al. & 40 & M & Dorsum of tongue & 15 & 7 & 14 \\
\hline 18 & 1986 & Ling & 22 & $\mathrm{~F}$ & Dorsum of tongue & 22 & 10 & 15 \\
\hline 19 & 1987 & Tohill et al. & 26 & $\mathrm{~F}$ & Dorsum of tongue & Not described & Not described & 16 \\
\hline 20 & 1987 & van der Wal et al. & 61 & $\mathrm{~F}$ & Dorsum of tongue & 20 & 15 & 17 \\
\hline 21 & 1987 & Weitzner et al. & 61 & M & Dorsum of tongue & Not described & 0.5 & 18 \\
\hline 22 & 1988 & West et al. & 5 & $\mathrm{~F}$ & Blind foramen of the tongue & 15 & 0.5 & 19 \\
\hline 23 & 1988 & Aguirre et al. & 53 & M & Dorsum of tongue & 10 & 3 & 20 \\
\hline 24 & 1989 & Ishibashi et al. & 79 & $\mathrm{~F}$ & Facies Inferior of tongue & 15 & 0.5 & 21 \\
\hline 25 & 1989 & Tani et al. & 75 & $\mathrm{~F}$ & Dorsum of tongue & 7 & 2 & 22 \\
\hline 26 & 1989 & Landini et al. & 35 & $\mathrm{~F}$ & Dorsum of tongue & 8 & 23 & 23 \\
\hline 27 & 1989 & Trowbridge et al. & 24 & $\mathrm{~F}$ & Margin of tongue & 20 & 5 & 24 \\
\hline 28 & 1990 & Munro et al. & 11 & M & Margin of tongue & 6 & 0.25 & 25 \\
\hline 29 & 1990 & Moore et al. & 35 & M & Dorsum of tongue & 10 & 10 & 26 \\
\hline 30 & 1990 & Sanchez-Aniceto et al. & 61 & M & Margin of tongue & 10 & 2 & 27 \\
\hline 31 & 1993 & Blum et al. & 60 & M & Buccal mucosa & 10 & 1 & 36 \\
\hline 32 & 1994 & Unal et al. & 11 & $\mathrm{~F}$ & Gingiva & 5 & 0.17 & 41 \\
\hline 33 & 1994 & Unal et al. & 16 & M & Gingiva & 10 & 2 & 41 \\
\hline 34 & 1998 & Mosquenda-Tayler et al. & 71 & $\mathrm{~F}$ & Dorsum of tongue & Not described & 2 & 28 \\
\hline 35 & 1998 & Mosquenda-Tayler et al. & 28 & $\mathrm{~F}$ & Dorsum of tongue & Not described & 1.5 & 28 \\
\hline 36 & 1998 & Mosquenda-Tayler et al. & 27 & M & Margin of tongue & Not described & 24 & 28 \\
\hline 37 & 2003 & Toida et al. & 3 & $\mathrm{~F}$ & Dorsum of tongue & 6 & 1 & 29 \\
\hline
\end{tabular}




\begin{tabular}{|c|c|c|c|c|c|c|c|c|}
\hline 38 & 2004 & Matsushita et al. & 68 & M & Gingiva & 20 & Not described & 42 \\
\hline 39 & 2005 & Onodera et al. & 47 & $\mathrm{~F}$ & Buccal mucosa & 40 & 1 & 37 \\
\hline 40 & 2005 & Sera et al. & 17 & M & Dorsum of tongue & 5 & Not described & 30 \\
\hline 41 & 2006 & Ide & 57 & $\mathrm{~F}$ & Hard palate & Not described & Not described & 40 \\
\hline 42 & 2006 & Ide & 41 & M & Hard palate & Not described & Not described & 40 \\
\hline 43 & 2007 & Mataix et al. & 42 & $\mathrm{~F}$ & Dorsum of tongue & 20 & 30 & 31 \\
\hline 44 & 2007 & Desmedt et al. & 66 & $\mathrm{~F}$ & Apex of tongue & Not described & Not described & 32 \\
\hline 45 & 2009 & Kim et al. & 8 & $\mathrm{~F}$ & Lower lip & 10 & 1 & 45 \\
\hline 46 & 2009 & Rossi-Schneider et al. & 73 & $\mathrm{~F}$ & Ventral of tongue & 7 & 3 & 33 \\
\hline 47 & 2010 & Kawano et al. & 59 & M & Hard palate & 15 & 4 & $\begin{array}{c}\text { Present } \\
\text { case }\end{array}$ \\
\hline
\end{tabular}

